\title{
Toxicity determination and hypoglycaemic effect of neem biopesticide on the grass carp "Ctenopharyngodon idella"
}

\author{
Hamdy M. A. Hassanein and Hanan A. Okail \\ Zoology Department, Faculty of Science, Sohag University, Sohag 82524, Egypt
}

\section{ABSTRACT}

The objective of this study was to determine the toxicity of the neem biopesticide (Triology); extracted from the neem tree, Azadirachta indica; on the grass carp fish "Ctenopharyngodon idella as well as investigation its hypoglycaemic effect on liver carbohydrates content and plasma glucose levels.

The obtained results showed that exposing the fish to gradual concentrations (ranged from 20 to $180 \mathrm{mg} / \mathrm{l}$ ) of this toxicant has led to abnormal symbtoms of the fish. These were charachterized by loss of balance, with an initial increase in the opercular ventilation rates which then decreased significantly. Moreover, darkening of the exposed fish, erratic swimming, and respiratory distress were observed prior to death. However, the calculated $96 \mathrm{~h} \mathrm{LC}_{50}$ of this pesticide was $112 \mathrm{mg} / \mathrm{l}$.

For investigation of the hypoglycaemic effect, fish were divided to three groups:

(i) Fish were exposed to $1 / 10 \mathrm{LC}_{50}(11.2 \mathrm{mg} / \mathrm{L})$ of the pesticide for 15 day, then sampled after intervals of 5,10 and 15 days post exposure which followed by 10 days recovery, then sampled after intervals of 5 and 10 days. (ii) Fish were exposed to $1 / 2$ $\mathrm{LC}_{50}(56 \mathrm{mg} / \mathrm{L})$ of neem pesticide for 6 days, then they were sampled after successive intervals of 2, 4 and 6 days of exposure followed by 6 days recovery where fish were sampled after intervals of 3 and 6 days. (iii) control group.

The results revealed that general carbohydrates; as illustrated by PAS-reaction in the liver; were subjected to gradual and marked reductions after different time intervals of exposure. At the end of recovery period, an improvement in the liver carbohydrate contents could be observed. Furthermore, the present investigations suggested that the two different treatments of $C$. idella with Triology have induced marked reduction in plasma glucose. However, during the both 2 recovery periods, the fish groups did not show complete recovery.

The data suggests that $A$. indica could be of benefit in diabetes mellitus in controlling the blood sugar or may also be helpful in preventing or delaying the onset of the disease.

Key words: Neem - A indica - biopesticide - Ctenopharyngodon idella - carbohydrates hypoglycaemia.

\section{INTRODUCTION}

Azadirachtin, a botanical pesticide derived from the neem tree, Azadirachta indica is one of the most promising natural compounds (Winkaler et al., 2007), where it is less harmful to the environment than the synthetic pesticides (Sundaram, 1996).

However, neem has been found to be toxic to non-target organisms where it induces marked alterations in experimental animals (Mahboob et al., 1998; Panda and Kar, 2000; Rahman et al., 2002 and Hassanein et al., 2007). 
Several researchers studied the toxic impacts of different neem extracts on glucose metabolism in experimental animals, In this regard, Sinniah et al. (1985) reported that administration of Morgosa oil (Mo) to laboratory rats caused decreasing of glucose level in the blood of Mo-treated animals. Moreover, oral administration of neem oil to rats at $200 \mathrm{mg} / \mathrm{rat}$ resulted in severe reduction in blood glucose levels (Dixit et al., 1986).

Also, the aqueous leaf extract of neem when orally fed, produces hypoglycemia in normal and diabetic rats (EL-Hawary and Kholief, 1990). Albino mice treated interperitoneally with $20 \mathrm{mg}$ neem seed oil (extracted from seed with petroleum ether) had significant reductions in blood glucose level after $4 \mathrm{~h}$ and $8 \mathrm{~h}$ of treatment (Purohit et al., 1990). Moreover, Narayan et al. (1993) reported that chronic administration of neem oil, to adult albino rats caused lowering blood glucose level. Similar observations have been reported in rats following oral administration of Vepacide (Rahman et al., 1996).

Khosla et al. (2000) observed hypoglycemic effect with Azadirachta indica when given as a leaf extract and seed oil, in normal as well as diabetic rabbits. Both the leaf extract and seed oil produced an approximately 35\% reduction in blood glucose levels in normal and alloxan diabetic rabbits.

Halim and Ali (2002) investigated the effect of oral feeding of water extract of fresh leaves of Azadirachta indica in streptozotocin induced diabetes in rats. They found that treatment of the diabetic rats with aqueous extract of leaves of A. indica resulted in significant fall in blood glucose level. In addition, Halim (2003) reported that the administration of combination (1:1) of water extract of dried powder of root and leaves (200 mg/kg bw) of Azadirachta indica and Abroma augusta to alloxan diabetic rats once a day for 8 weeks caused significant lowering of blood sugar. Furthermore, Kar et al. (2003) studied the effect of 30 Indian medicinal plants on alloxan diabetic rats. They found that 24 plants including (A. indica) induced hypoglycaemic effects.

\section{MATERIALS AND METHODS}

\section{Fish Samples:}

Healthy samples of grass carp "Ctenopharyngodon idella" were collected from fish farm at El-Ahaiwa, Sohag Governorate. The fish were transported in well aerated large containers to the laboratory, and then were kept in well aerated aquaria for 10 days to get acclimatized for the laboratory conditions before the start of experiments. The fish were fed on grass during this period.

\section{The pesticide:}

The biopesticide used in the present work is the neem oil extract (trade name: Triology), a product of Thermo Triology Corp., USA. It was used as commercial material of a concentration of $90 \mathrm{~g} / 100 \mathrm{ml}$ from which different dilutions were prepared by emulsification in water.

\section{Determination of $\mathrm{LC}_{50}$ :}

To determine the median lethal concentration $\left[\mathrm{LC}_{50}\right]$ of neem pesticide which causes $50 \%$ live-death response at 96 hours. Groups of 10 fish were exposed to gradual concentrations of the pesticide for 96 hours. $\mathrm{LC}_{50}$ value was obtained by plotting the percentage of mortality versus concentration on semi-log paper according to the method of Sparague (1969). 


\section{Experimental design:}

Fish were divided into 3 groups, the first group was kept in pesticide-free water and served as control and the second one was exposed to $1 / 10 \mathrm{LC}_{50}(11.2 \mathrm{mg} / \mathrm{L})$ of the neem pesticide for 15 days, the fish were sampled after intervals of 5,10 and 15 days post exposure followed by 10 days recovery in free water, then sampled after the intervals of 5 and 10 days while the third group was exposed to $1 / 2 \mathrm{LC}_{50}(56 \mathrm{mg} / \mathrm{L})$ of neem pesticide for 6 days, then they were sampled after 2, 4 and 6 days of exposure followed by 6 days recovery where fish were sampled after 3 and 6 days. At the end of each exposure time 10 samples of treated as well as control fish, were used for further investigations.

\section{Investigation:}

The liver was excised immediately after decapitation and small pieces were fixed in carnoy's fluids. The $5 \mu$ sections were stained using PAS reaction (Drury and Wallington 1980), examined and photographed as required. Furthermore, a part of liver from each fish was homogenized and then centrifuged at 10000 r.p.m. for 15 minutes; the supernatant was separated and stored at $-20^{\circ} \mathrm{C}$ until used. Also, plasma was obtained by centrifugation of the blood samples at 10000 r.p.m. for 20 minutes. Clear plasma was stored at $-20^{\circ} \mathrm{C}$ until used for determination of glucose level according to the method of Barham and Trinder (1972).

\section{Statistical analysis:}

The data obtained in the present work were expressed as mean $\pm \mathrm{SE}$ and were statistically analyzed using student t-test (Milton and Tsokos, 1983) to compare means of treated data against their control ones and the results were considered significant at $\mathrm{P}<0.05$.

\section{RESULTS}

\section{Determination of $\mathrm{LC}_{\mathbf{5 0}}$ :}

Exposing the fish to gradual concentrations of the neem biopesticide (Triology) has led to abnormal behaviour of the fish. This was charachterized by loss of buoyancy and balance, with an initial increase in the opercular ventilation rates which then decreased significantly. Prior to death, darkening of the exposed fish, erratic swimming, and respiratory distress were observed.

However, by exposing groups of 10 fish of grass carp "Ctenopharyngodon idella to gradual concentrations of the used pesticide for 96 hours, $\mathrm{LC}_{50}$ value could be calculated via plotting the percentage of mortality versus the concentration on a semi-log paper (Fig.1). The median lethal concentration [ $\left.\mathrm{LC}_{50}\right]$ of this pesticide, which causes $50 \%$ live-death response was $112 \mathrm{mg} / \mathrm{l}$ (Table 1 and Fig. 1).

Table (1): Mortality percentages caused by the neem biopesticide Triology to Ctenopharyngodon idella

\begin{tabular}{|c|c|}
\hline Concentration $(\mathrm{mg} / \mathrm{l})$ & \%Mortality \\
\hline 20 & - \\
\hline 40 & - \\
\hline 60 & 10 \\
\hline 80 & 20 \\
\hline 100 & 40 \\
\hline 120 & 60 \\
\hline 140 & 70 \\
\hline 160 & 80 \\
\hline 180 & 90 \\
\hline
\end{tabular}




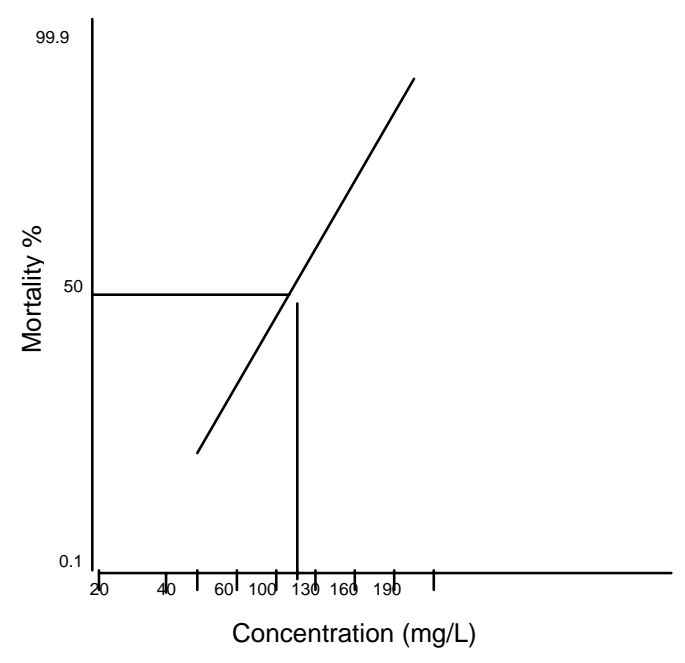

Fig. (1): Lethal -mortality curve of Triology using C. Idella.

\section{Effect of Triology on carbohydrates i-General carbohydrates in liver Normal fish:}

In the normal liver of Ctenopharyngodon idella, a large amount of carbohydrates was observed in the cytoplasm of the hepatocytes as indicated by the intense PAS- Positive reaction (magenta colouration) (plate $1 \mathrm{a}$ ).

\section{Treated fish:}

\section{Effect of 1/10 LC 50:-}

Examination of liver tissue of fish treated with $1 / 10 \mathrm{LC}_{50}(11.2 \mathrm{mg} / \mathrm{L})$ for 5 days has indicated normal pattern of carbohydrate contents in the cytoplasm of the hepatocytes (plate $1 \mathrm{~b}$ ). After 10 days of the pesticide exposure, carbohydrate contents of the liver tissues were slightly decreased in the hepatocytes (plate $1 \mathrm{c}$ ). A higher degree of carbohydrates depletion was detected after exposing the experimental fish to the same concentration of the pesticide for 15 days (plate $1 \mathrm{~d}$ ).

During the recovery period, the depletion of general carbohydrates in liver tissue was reduced after 5 and 10 days of recovery period (plate 1 e $\&$ f).

\section{Effect of 1/2 $\mathrm{LC}_{50}$ :-}

Following exposure of fish to $1 / 2 \mathrm{LC}_{50}(56 \mathrm{mg} / \mathrm{L})$ of Triology ${ }^{\circledR}$ for 2 days, carbohydrate contents of the liver tissues were slightly decreased in the hepatocytes (plate 2 a) as compared with normal control group. The above reduction of carbohydrate contents became more marked in the liver cells of fish exposed to the same concentration of the pesticide for 4 days of $1 / 2 \mathrm{LC}_{50}$ exposure (plate $2 \mathrm{~b}$ ). Later on, when material was examined after 6 days of treatment, carbohydrate contents loss was more pronounced in the hepatic tissues of the treated fish (plate $2 \mathrm{c}$ ). These changes in carbohydrate contents were sustained after 3 days of recovery period (plate 2 d). Furthermore, at the end of recovery period (6 days), an improvement in the liver carbohydrate contents was observed (plate 2 e).

\section{ii- Plasma glucose}

Effect of 1/10 $\mathrm{LC}_{50}$ :-

Application of Triology ${ }^{\circledR}$ as $(11.2 \mathrm{mg} / \mathrm{L})$ for 15 days induced marked decrease in plasma glucose level (Table 2). Statistically, the change in plasma glucose level was highly significant $(\mathrm{P}<0.01)$ after 5 days and significant $(\mathrm{P}<0.05)$ after 10 and 15 
days, these levels were $41.47 \pm 6.1,54.04 \pm 2.07$ and $51.9 \pm 2.6 \mathrm{mg} / \mathrm{dl}$ after 5,10 and 15 days of treatment respectively.

During the recovery period, the fish groups showed a decrease in plasma glucose level which recorded $28.23 \pm 1.02$ and $43.98 \pm 1.71 \mathrm{mg} / \mathrm{dl}$ after 5 and 10 days respectively (Table 2). From the statistical point of view, these changes were highly significant $(\mathrm{P}<0.001)$.

Table (2): Changes in plasma glucose concentration (mg/dl) of C. idella after exposure to 1/10 LC50 of Triology for 15 days followed by 10 days recovery.

\begin{tabular}{|c|c|c|c|c|}
\hline $\begin{array}{c}\text { Experimental } \\
\text { design }\end{array}$ & Days & Mean \pm SE & $\begin{array}{c}\% \text { of } \\
\text { change }\end{array}$ & $\begin{array}{c}\text { Significance } \\
\text { level }\end{array}$ \\
\hline Control & 0 & $74.01 \pm 6.6$ & 0 & \\
\hline \multirow{2}{*}{$\begin{array}{c}\text { Exposure } \\
\text { period }\end{array}$} & 5 & $41.47 \pm 6.1$ & -47.4 & $* *$ \\
\cline { 2 - 5 } & 10 & $54.04 \pm 2.07$ & -26 & $*$ \\
\hline \multirow{2yyyy}{*}{$\begin{array}{c}\text { Recovery } \\
\text { period }\end{array}$} & 5 & $51.9 \pm 2.6$ & -29 & $* *$ \\
\cline { 2 - 5 } & 10 & $43.98 \pm 1.71$ & -40 & $* *$ \\
\hline
\end{tabular}

** highly significant

* significant

\section{Effect of 1/2 $\mathrm{LC}_{50}$ :-}

The plasma glucose level of treated fish had represented a decrease after treatment with $1 / 2 \mathrm{LC}_{50}(56 \mathrm{mg} / \mathrm{L})$ of the used pesticide for 6 days. Statistically, the change in plasma glucose level was non-significant $(\mathrm{P}>0.05)$ after 2 days and significant $(\mathrm{P}<0.05)$ after 4 and 6 days (Table 3$)$. The plasma glucose levels were $58.1 \pm 0.75,51.8 \pm 1.7$ and $56.5 \pm 1.6 \mathrm{mg} / \mathrm{dl}$ after 2,4 and 6 days of treatment respectively.

The fish groups in untreated water (recovery period) had exhibited a marked and highly significant $(\mathrm{P}<0.01)$ decrease in the plasma glucose level. The highest decline in plasma glucose level $(31.57 \pm 1.38 \mathrm{mg} / \mathrm{dl})$ was recorded after 3 days of recovery period while after 6 days (the end of recovery period) the decrease in plasma glucose level was $35.44 \pm 2.6 \mathrm{mg} / \mathrm{dl}$ as shown in Table (3).

Table (3): Changes in plasma glucose concentration $(\mathrm{mg} / \mathrm{dl})$ of $C$. idella after exposure to $1 / 2$ LC50 of Triology for 6 days followed by 6 days recovery.

\begin{tabular}{|c|c|c|c|c|}
\hline $\begin{array}{c}\text { Experimental } \\
\text { design }\end{array}$ & Days & Mean \pm SE & $\begin{array}{c}\% \text { of } \\
\text { change }\end{array}$ & Significance level \\
\hline Control & 0 & $74.01 \pm 6.6$ & & \\
\hline \multirow{2}{*}{$\begin{array}{c}\text { Exposure } \\
\text { period }\end{array}$} & 2 & $58.1 \pm 0.75$ & -21 & $*$ \\
\cline { 2 - 5 } & 4 & $51.8 \pm 1.7$ & -42 & $*$ \\
\hline \multirow{2}{*}{$\begin{array}{c}\text { Recovery } \\
\text { period }\end{array}$} & 3 & $56.5 \pm 1.6$ & -23 & $* *$ \\
\cline { 2 - 5 } & 6 & $31.57 \pm 1.38$ & -57 & $* *$ \\
\hline
\end{tabular}

\footnotetext{
** highly significant

* significant

${ }^{\circ}$ non-significant
} 


\section{DISCUSSION}

In the present work, an attempt has been made to study the toxicity of the neem pesticide Triology to C.idella by estimation of the median lethal concentration $\left[\mathrm{LC}_{50}\right]$. Moreover, investigation of its impacts on general carbohydrate contents in the liver by using the conventional histochemical methods as well as glucose level in plasma, the main target behind this double faced mode of investigation is to reach proper and concrete interpretation of the obtained results.

The estimated $\mathrm{LC}_{50}$ was $112 \mathrm{mg} / \mathrm{L}$. The Triology led to an initial increase in the opercular ventilation rates which then decreased significantly. Prior to death, darkening of the exposed fish, erratic swimming, and respiratory distress were observed. Similar behavioral changes were observed by many investigators (Jayaraj, 1992; Fernardez et al., 1992; Omoregie and Okpanachi, 1997; Oti and Ukpabi, 2004 and Mondal, et al., 2007) who demonstrated that various neem preparations induce toxicity to different experimental fish species. The authors believed that mortality may be due to fatigue and direct toxic effects of the pesticide on the fish tissues.

The toxicity of different neem pesticides and different neem extracts on other non-target aquatic organisms have been estimated by previous investigators (Singh et al., 1996; Dunkel and Richardsi, 1998; El-Shazly and El-Sharnoubi, 2000 and Scott and Kaushik, 2000).

El-Shazly and El-Sharnoubi (2000) found that neem based insecticides compound was more or less toxic to 5 tested organisms. The $\mathrm{LC}_{50}$ and mortality rates were determined, the most tolerant species were the larvae of Bufo regularis $\left(\mathrm{LC}_{50}\right.$ $=53 \mathrm{ppm}$ ) and Aedes caspius. $\left(\mathrm{LC}_{50}=47 \mathrm{ppm}\right.$ ) (Insecta). However, Gambusia affinis intermidiated sensitivity to the insecticide $\left(\mathrm{LC}_{50}=39 \mathrm{ppm}\right)$, while the Crustacean species Cyclops sp. $\left(\mathrm{LC}_{50}=31 \mathrm{ppm}\right)$ and Daphnia magna $\left(\mathrm{LC}_{50}=27 \mathrm{ppm}\right)$ were sensitive to relatively low concentrations of Neem Azal insecticide. Moreover, Scott and Kaushik (2000) reported that the use of botanical insecticide Margosan-O and possibly other neem extracts in/or near aquatic environments could lead to disturbances in benthic populations and may cause decreases in numbers of organisms that are important in food web and nutrient cycling processes.

\section{Tissue general carbohydrates:}

It was found that treatment with the two different concentrations of Triology had induced marked reduction in carbohydrate contents of the fish liver. Moreover, the depletion of carbohydrate contents in the liver which observed in all examined samples during the two exposure periods have started to recover after removing of the pesticide where the carbohydrate contents in the liver showed improvement until the end of the two recovery periods.

To the best of the authors knowledge, the published studies on the effect of neem or its derivatives on carbohydrates in fish tissues are scarce. However, Sinniah et al. (1985) found glycogen depletion in histological sections of the livers after administration of Morgosa oil (Mo) to laboratory rats. Moreover, Manoranjitham et al., (1993) found that the administration of neem seed oil to adult male wistar rats at 250 and $500 \mathrm{mg} / \mathrm{kg}$ bw/day for 8 days induced a marked decrease in the glycogen levels in testes at both doses. In addition, Chattopadhyay et al. (1993) reported that the reason for depletion of hepatic glycogen by A.indica extract in presence of glucose load is not very clear. Similar changes were reported by the other authors (Koundinya and Ramamurthi, 1979; Singh and Srivastava, 1981; Srivastava and Singh, 1982 and 
Hassanien, 1999) who used the synthetic pesticides. In this concern, Koundinya and Ramamurthi (1979) reported reduction in the levels of glycogen in the liver and muscles of Tilapia mossambica after treatment with $6 \mathrm{mg} / \mathrm{L}\left(48 \mathrm{~h} \mathrm{LC}_{50}\right)$ of the fenitrothion pesticide. Also, Singh and Srivastava (1981) mentioned that exposure of catfish, Heteropenustes fossilis to a sublethal concentration of a mixture of aldrin and formothion pesticides induced a marked decrease in the glycogen content of the liver and muscles of this fish. Similar results were observed on carbohydrates metabolism in the same fish ( $H$. fossilis) after treatment with propoxur pesticide (Srivastava and Singh, 1982). Furthermore, Murty and Devi (1982) illustrated similar changes in the glycogen content of the liver and muscles of the fish Channa punctatus after exposure to endosulfan. In addition, Gabr (1986) found that treatment of Tilapia nilotica with different concentrations of diazinon had initiated marked reductions of glycogen inclusions in the brain, liver and kidney tissues of this fish. Similarly, Hassanien (1999) observed that the different treatments of O. niloticus with goal had induced gradual and marked reduction in carbohydrate contents of both the liver and kidney.

Reduction in carbohydrate content in liver tissue in the present study may be due to the result of greater stress of used pesticide on vital organs and to the fish's need for energy necessary to resist stress or may be due to hypoxia.This assumption is supported by the findings of Heath and Fritechard (1965) and Umminger (1977) who reported that carbohydrate represents the principal and immediate energy source for animals exposed to stress conditions. Also, liver glycogen level is depleted during acute hypoxia or physical disturbance in the fish.

The present results revealed that the two different treatments of $C$. idella with Triology have induced a marked reduction in plasma glucose level. The present results are in agreement with those of many authors (Luscombe and Taha, 1974; Murthy et al., 1978; Pillai and Santhakumari, 1981; Sinniah et al., 1985; EL-Hawary and Kholief, 1990; Narayan et al., 1993 and Bopanna et al., 1997) who investigated the effect of different extracts of A.indica on blood glucose of different experimental animals and these studies revealed that A.indica is an effective antihyperglycemic agent in animals. In this regard, (Rahman et al., 1996) observed that neem based pesticides (Vepacide) has showed a significant decrease of serum glucose level in rats. Also, Luscombe and Taha (1974) reported that a marked drop in blood glucose concentration occurred after administration of aqueous extract of neem leaves to rabbits. In the present study, the reported hypoglycemia may be due to the highly toxic neem and/or an decrease in plasma concentration of catecholamines and adrenaline as a stress response of fish to neem pesticide. In support of this assumption, Murthy et al. (1978) observed that aqueous extract of neem leaves significantly decrease blood suger level, and prevents adrenaline induced hyperglycemia. Furthermore, Pillai and Santhakumari (1981) found a significant hypoglycemic effect observed by feeding neem oil to fasting rabbits.

Moreover, Sinniah et al. (1985) reported that administration of Morgosa oil (Mo) to rats caused decrease of glucose level in the blood with liver glycogen depletion. Furthermore, the aqueous leaf extract also reduces hyperglycemia in streptozotocin diabetic rats (EL-Hawary and Kholief, 1990). Furthermore, chronic administration of neem oil, to adult albino rats caused lowering blood glucose level (Narayan et al., 1993). In addition, Bopanna et al. (1997) reported that administration of neem kernel powder (NKP) alone $(500 \mathrm{mg} / \mathrm{kg}$ ) as well as the combination of NKP $(250 \mathrm{mg} / \mathrm{kg})$ with glibenclamide $(0.25 \mathrm{mg} / \mathrm{kg}$ bw) significantly decreased the concentration of serum blood glucose level on alloxan diabetic rats. The authors added that these changes were significantly greater when the treatment was given in 
combination of NKP and glibenclamide than with NKP alone. Halim and Ali (2002) found that treatment of the diabetic rats with aqueous extract of leaves of $A$. indica at a dose of $250 \mathrm{mg} / \mathrm{kg}$ bw resulted in a significant fall in blood glucose level. In addition, Halim (2003) reported that the administration of combination (1:1) of water extract of dried powder of root and leaves $(200 \mathrm{mg} / \mathrm{kg} \mathrm{bw})$ of Azadirachta indica and Abroma augusta to alloxan diabetic rats, caused a significant lowering of blood sugar in diabetic rats. Furthermore A. indica leaf extract was found to have the most potent blood sugar-lowering activity than other three important medicinal plants (Chattopadhyay, 1999a). Also, Kar et al. (2003) found the same results when they studied the comparative evaluation of hypoglycemic activity of 30 Indian medicinal plants in alloxan diabetic rats, one of these plants is $A$. indica.

Conversely, the present results disagree with those of Winkaler et al. (2007) who reported higher plasma glucose levels in the fish Prochilodus lineatus exposed to neem extract. This increase in blood glucose can be viewed as part of a stress response triggered by the presence of neem extract in water (Winkaler et al., 2007). Hyperglycemia has also been found in P. lineatus acutely exposed to lead for 6, 12 and $24 \mathrm{~h}$ (Martinez et al., 2004).

There are two possible mechanisms of the hypoglycemia action of neem which observed during the present work as well as in the previous studies. The first mechanism may be attributed to the the blocking of neem action on epinephrine, this suggestion is in accordance with Chattopadhyay (1996). Because epinephrine has been reported to induces hyperglycemia due to its dual action on carbohydrate metabolism; it causes increased liver glycogenolysis and reduction in peripheral utilization of glucose (Feldman and Lebovitz, 1970). The second hypothesized mechanism may be due to the blocking impact of neem on the inhibitory effect of serotonin on insulin secretion (Chattopadhyay, 1999b). It is worthy to mention that several publications have suggested the hypoglycemic action of neem but the authors reported that the reason is not very clear. However, further work is needed to pinpoint the extract mechanism(s) of the hypoglycemic effect of neem extracts.

\section{REFERENCES}

Barham, D. and Trinder, P. (1972). An improved colour reagent for the dertirmination of blood glucose by the oxidase system. Analyst., 97:142-145.

Bopanna, K. N.; Kannan, J.; Sushma, G.; Balaraman, R. and Rathod, S. P. (1997). Antidiabetic and antihyperlipaemic effects of neem seed kernel powder on alloxan diabetic rabbits Indian J. Pharmacol., 29: 162-167.

Chattopadhyay, R. R. (1996). Possible mechanism of antihyperglycemic effect of Azadirachta indica leaf extract. Part IV. Gen Pharmacol., 27(3):431-434.

Chattopadhyay, R. R. (1999a). Possible mechanism of antihyperglycemic effect of Azadirachta indica leaf extract: part V. J Ethnopharmacol., 67(3):373-376.

Chattopadhyay, R. R. (1999b). A comparative evaluation of some blood sugar lowering agents of plant origin. J. Ethnopharmacol., 67(3):367-372.

Chattopadhyay, R. R.; Chattopadhyay, R. N. and Maitra, S. K. (1993). Effect of Azadirachta indica leaf extract on hepatic glycogen in rats. Indian $\mathrm{J}$. Pharmacol., 25:174- 175.

Dixit, V. P.; Sinha, R. and Tank, R. (1986). Effect of Neem seed oil on the blood glucose concentration of normal and alloxan diabetic rats. J. Ethnopharmacol., 17(1):95-108. 
Drury, R. A .B. and Wallington, E. A. (1980). Carleton's Histological technique, $5^{\text {th }}$. Oxford University press.

Dunkel, F. V. and Richardsi, D. C. (1998). Effect of an azadirachtin formulation on six nontarget aquatic macroinvertebrates .Environ. Entomol., 27(3): 667-674.

El-Hawary, Z. M. and Kholief, T. S. (1990). Biochemical studies on hypoglycemic agents (1) Effect of Azadirachta indica leaf extract. Archives of Pharmacol Research., 13 (1): 108-112.

El-Shazly, M. M. and El-Sharnoubi, E. D. (2000). Toxicity of a Neem (Azadirachta indica) insecticide to certain aquatic organisms. J. Egypt. Soc. Parasitol., 30(1):221-31

Feldman, J. M. and Lebovitz, H. E (1970). Mechanism and epinephrine and serotonin inhibition of insuline relase in the golden hamster in vitro. Diabetes., 19:480-478.

Fernardez, N. J.; Planginan, E. L.; Soon, L. L. and Botterell, D. G. (1992). Impact of neem on nontarget organisms. Proc. Final Workshop, Botanical Pest Control proj. Phase 2 (IRRI,Los Banos, Philippines), pp 117-121.

Gabr, S. A. (1986). Physiological, biochemical and morphological studies on the effect of insecticides on the fish of Dam Lake. PH. D. Thesis, Fac. Sci. (Aswan) Assiut Univ.

Halim, E. M . (2003). Lowering of blood sugar by water extract of Azadirachta indica and Abroma augusta in diabetes rats. Indian. J. Exp. Biol., 41(6):636640.

Halim, E. M. and Ali, H. (2002). Reversal of diabetic retinopathy in streptozotocin induced diabetic rats using traditional indian anti-diabetic plant, Azadirachta indica (1.). Indian J. Clin. Biochem.,17(2):115-123.

Hassanein, H. M. A. (1999). Histopathological, histochemical and physiological studies on the effect of environmental pollution with the herbicides"Goal" on the liver and kidney of the Nile bolti "Oreochromis niloticus" in Sohag Governorate. Ph.D. thesis, Fac. Sci., Sohag, South Valley Univ.

Hassanein, H. M. A; okail ,H. A. and Mohamed , N.K. (2007). Biochemical changes in proteins and DNA in Ctenopharyngodon idella due to environmental pollution with the biopesticide (Trilogy). 10 ICCA , Garyounis university, Benghazi, Libya . 18-21 . Nov . 2007.

Heath, A. G. and Fritechard, A.W. (1965). Effect of severe hypoxia on carbohydrate energy. Stores and metabolism in two species of freshwater fish. Physiol. Zool., 38: 325- 334.

Jayaraj, S. (1992). Studies on IMP in rice-based cropping system with emphasis on use of botanicals, their safty, and socioeconomics considerations. Proc. Final Workshop, Botanical Pest Control proj. Phase 2 (IRRI,Los Banos, Philippines)., pp 63-78.

Kar, A.; Choudhary, B. K. and Bandyopadhyay, N. (2003). Comparative evaluation of hypoglycemic activity of some Indian medicinal plants in alloxan diabetic rats. J. Ethnopharmacol., 84 (1):105-108.

Khosla, P.; Bhanwra, S.; Singh, J.; Seth, S. and Srivastava, R. K. (2000). A study of hypoglycemic effects of Azadirachta indica (Neem) in normal and alloxan diabetic rabbits.Indian J Physiol Pharmacol., 44(1):69-74.

Koundinya, P. R. and Ramamurthi, R. (1979). Effect of organophosphate pesticide sumithion (Fenitrothion) on some aspects of carbohydrate metabolism in a fresh water fish Tilapia mossambica (Peters). Experientia., 35: 1632-1639. 
Luscombe, D. K. and Taha, S. A. (1974). Pharmacological studies on the leaves of Azadirachta indica . J. pharm. Pharmacol., 26 (supplement) 110 pp.

Mahboob, M.; Siddiqui, M. K. J. and Jamil, K. (1998). The effect of subacute administration of a neem pesticide on rat metabolic enzymes. J. Environ.1 Sci. Health., B33.,(4): 425-438.

Manoranjitham, M. P.; Prem Anandhi, A.; Sampathraj, R. and Vanithakumari, C. (1993). Alteration of testicular architecture following neem oil administration in albino rats. Proceedings of the World Neem Conference. Bangalore. India., pp 1165-1172.

Martinez, C. B. R.; Nagae, M. Y.; Zaia, C. T. B. V. and Zaia, D. A. M. (2004). Morphological and physiological acute effects of lead in the neotropical fish Prochilodus lineatus. Braz. J. Biol. 64: 797-807.

Milton, T. S. and Tsokos, J. O. (1983). Statistical methods in the biological and health science. McGraw-will. Internat. Book Comp., pp 381- 405.

Mondal, D.; Barat, S. and Mukhopadhyay, M. K. (2007). Toxicity of neem pesticides on a fresh water loach Lepidocephalichthys guntea (Hamilton Buchanan) of Darjeeling district in west Bengal. J. Environ. Biol. 28 (1): 119-122.

Murthy, K. S.; Rao, D. N.; Rao, D. K. and Murthy, L. B. G. (1978). A preliminary study on hypoglycemic and antihyperglycemic effects of Azardirachta indica. Indian. J. Pharmacol., 10:247-8.

Murty, A. S. and Devi, A. P. (1982). The effect of endosulifan and its isomers on tissue protein, glycogen and total lipids in the fish Channa punctata. Pestic. Biochem. Physiol., 17(3): 280-286.

Narayan, P. B. S.; Sampathraj, R. and Vanithakumari, G. (1993). Rat- toxicity studies with neem oil. World Neem Conf. (Banngalore, India ), p55.

Omoregie, E. and Okpanachi, M. A. (1997). Acute toxicity of water extracts of bark of the neem plant, Azadirachta indica (Lodd) to cichlid, Tilapia zillii (Gervais). Acta. Hydrobiol., 39: 47-51.

Oti, E. E. and Ukpabi, U. H. (2004). Acute Toxicity of Water Extracts of Barks of Yellow Oleander, Thevetia peruviana (Persoon), and Neem Plant, Azadirachta indica (Lodd) to Mormyrids, Hyperopisus bebe occidentalis (Gunther). J. App.Aquacu., 16: 183 - 190.

Panda, S. and kar, A. (2000). How safe is neem extract to thyroid function in male mice. Pharmacol. Res., 41(4): 419-422.

Pillai, N. R. and Santhakumari, G. (1981). Hypoglycemic activity of Melia Azrdirachta Linn (neem). Indian J. Med. Res., 74:931-393.

Purohit, A.; Joshi, V. B. and Dixit, V. P. (1990). Contraceptive efficacy of Azadirachta indica (flower and bark) in male rats. A biochmical and sperm dynamics analysis. J. Curr. Bio.sci., 7(4): 129-133.

Rahman, M. F.; Siddiqui, M. K. J. and Jamil, K. (2002). LDH profiles of male and female rats treated with Vepacide. J. Phytother Res., 16 (2):122-126.

Rahman, M. F.; Siddiqui, M. K. J. and Mustafa, M. (1996). Effect of repeated oral administration of Vepacide (Azadirachta indica) on some haematological and biochemical parameters in rats. Indian J. Toxicol., 3 (1): 1-8.

Scott, I. M. and Kaushik, N. K. (2000). Toxicity of a neem insecticide to populations of culicidae and other aquatic invertebrates as assessed in situ microcosms. Arch Environ. Contam. Toxicol., 39 (3):329-336. 
Singh, N. N. and Srivastava, A. K. (1981). Effect of a paired mixture of aldrin and formothion on carbohydrate metabolism in a fish Heteropneustes fossilis. Pestic. Biochem. Physiol., 15 (3): 257-261.

Singh, K.; Singh, A. and Singh, D. K. (1996). Molluscicidal activity of neem (Azadirachta indica A. Juss). J. Ethnopharmacol., 52 (1):35-40.

Sinniah, D.; Schwartz, P. H.; Mitchell, R. A. and Arcinue, E. L. (1985). Investigation of an animal model of a Reye-like syndrome caused by Margosa oil. Pediatr Res., 19 (12): 1346-1355.

Sparague, J. B. (1969). Review paper : Measure of pollutant toxicity to fish 1. Bioassay method for acute toxicity. Water Res. 3: 793-821.

Srivastava, A. K. and Singh, N. N. (1982). Acute toxicity of propoxur on carbohydrate metabolism on indian catfish Heteropeneustes fossilis., Toxicol. Lett., 11(1-2): 31-34.

Sundaram, K. M. S. (1996). Azadirachtin, biopesticide: a review of studies conducted on its analytic chemistry, environmental behaviour and biological effects. J. Environm. Science Health B, 3: 913-948.

Umminger, B. L. (1977). Relation of whole blood sugar concentration invertebrate to standard metabolic rate. Comp. Biochem. Physiol., 55: 457-460.

Winkaler, E. U.; Santos, T. R. M.; Joaquim G. Machado-Neto, J. G. and Martinez, C. B. R. (2007). Acute lethal and sublethal effects of neem leaf extract on the neotropical freshwater fish Prochilodus lineatus. Comp. Biochem. Physiol. C 145: 236-244. 

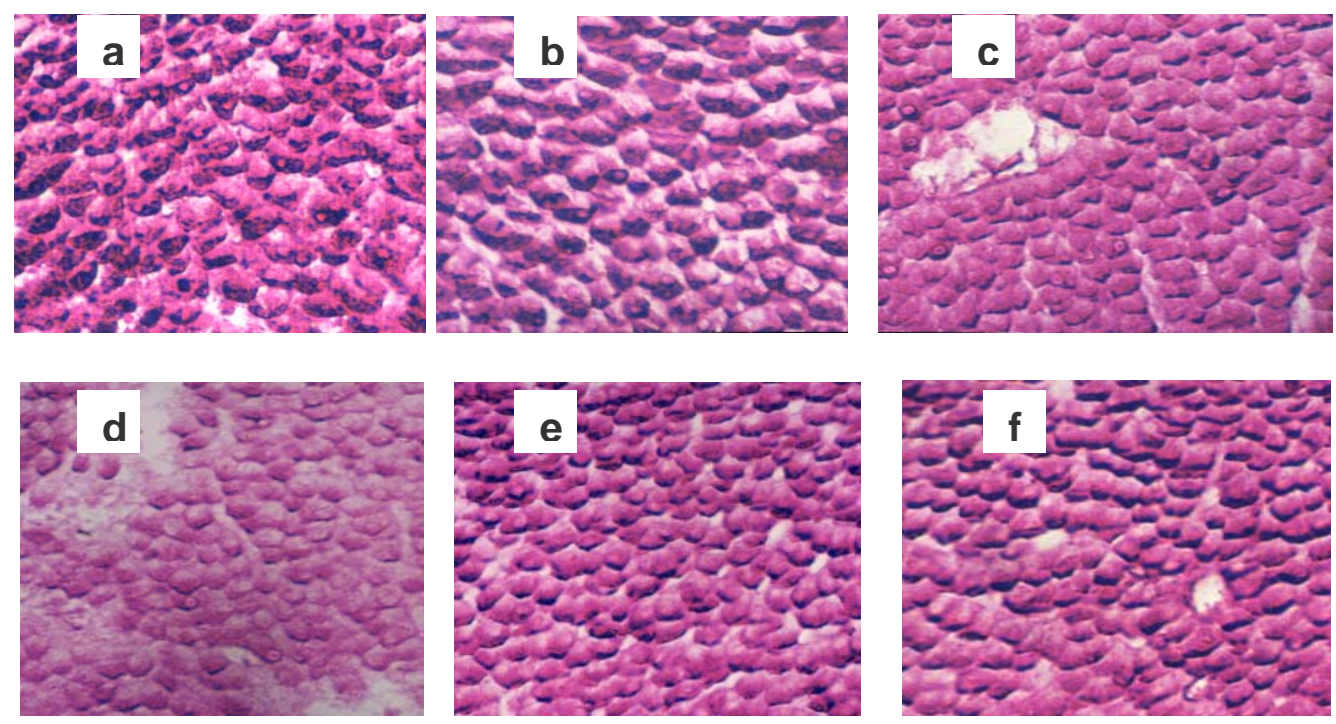

Plate 1 :(T.S in liver of Ctenopharyngodon idella (Fish)).

a: Liver of control fish stained with PAS-reaction, showing the normal carbohydrate contents. b: liver of fish treated with $1 / 10 \mathrm{LC}_{50}$ of Triology ${ }^{\circledR}$ for 5 days, showing also the normal carbohydrate contents. c: liver of fish treated for 10 day, showing decrease of carbohydrate contents. d: liver of fish treated for 15 days, showing strong decrease of carbohydrate contents. E\&f: liver of fish after 5 and 10 days of recovery period, showing an improvement in the carbohydrate contents. X 400
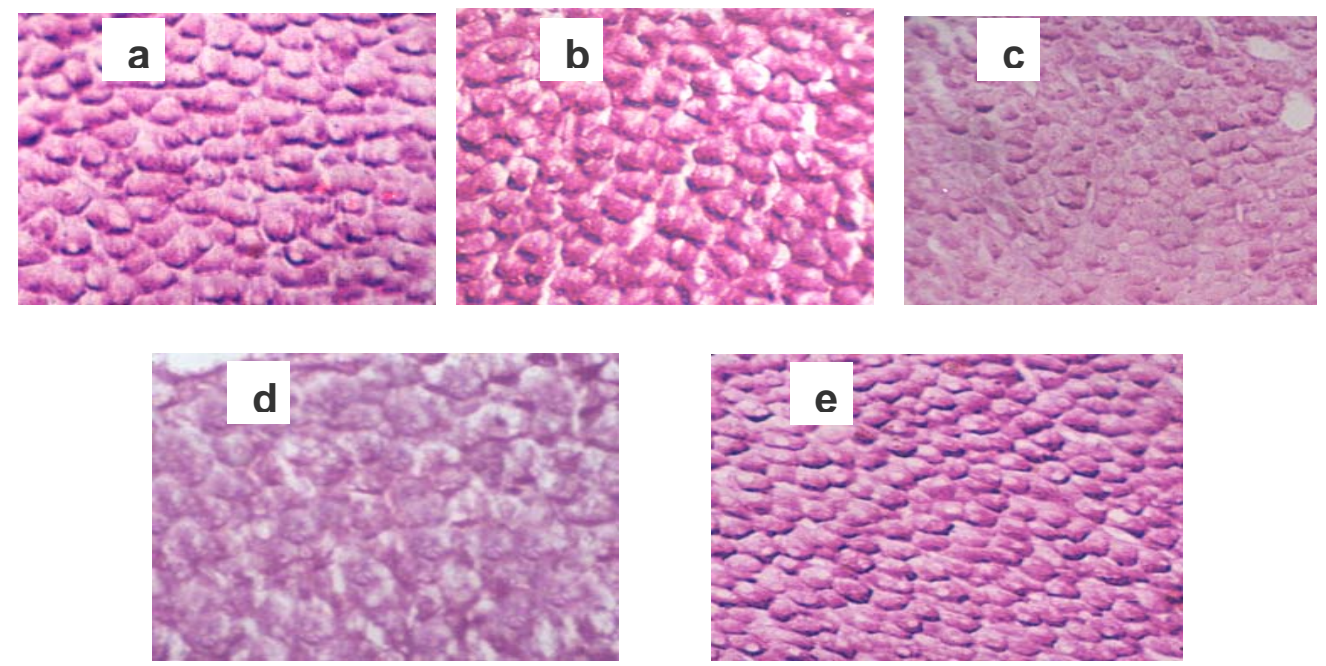

Plate 2: (T.S in liver of Ctenopharyngodon idella (Fish)).

a: Liver of fish treated with $1 / 2 \mathrm{LC}_{50}$ of Triology ${ }^{\circledR}$ for 2 day, showing slightly decreased carbohydrates as compared to control. b: liver of fish after 4 days of treatment showing decrease in carbohydrate contents. c: strong decrease in carbohydrate contents after 6 days. d: liver of fish after 3 days of recovery period, showing a decrease in carbohydrate contents. e: liver of fish after 6 days of recovery period, showing an improvement in its content of carbohydrates. PAS-reaction. X400 


\title{
تقدير السمية والتأثير الخافض للسكر لمبيا النيم الحيوى فى مبروك الحشائش (تينوفارينجودون ايدلا).
}

\author{
حمدى محمود أحمد حسانين و حنان على عقيل

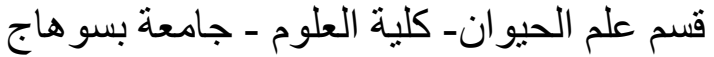

تهدف الدر اسـة الحاليـة إلى تقدير سمية المبيد الحيوى المستخلص من أثنجار النيم و المسمى تجاريا

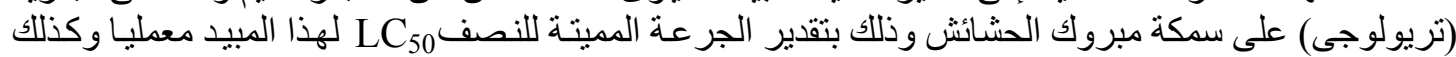

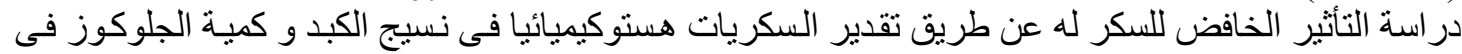

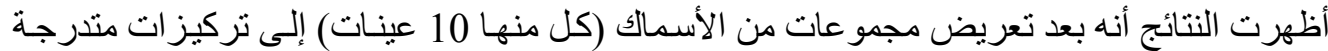

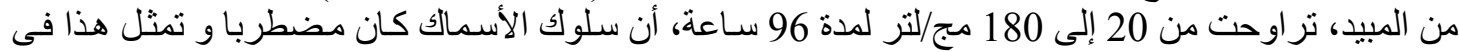

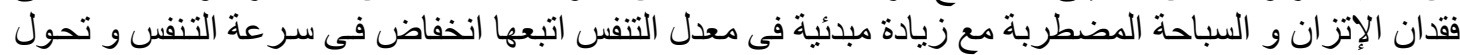

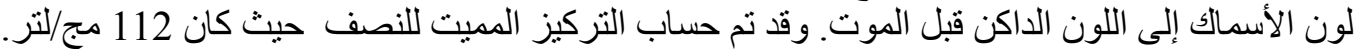

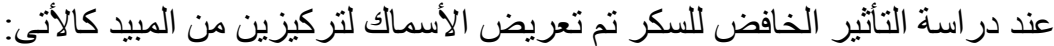
(i) تم تعرض الأسماك إلى التركيز (1/10 LC LC

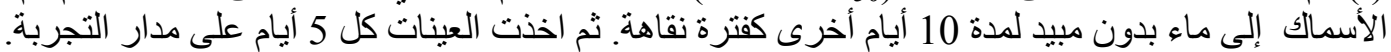
(ii)

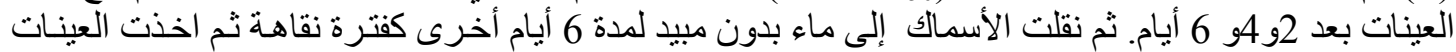

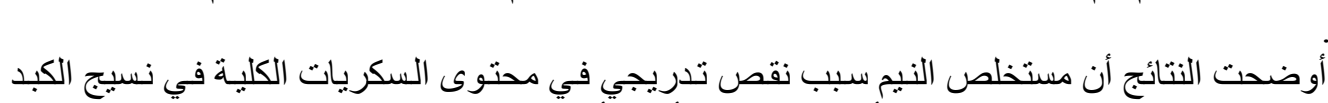
كل 3 أيام.

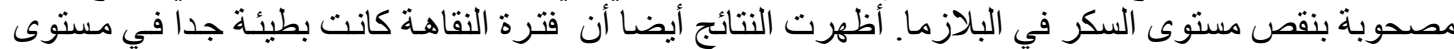
السكر في البلازما مع وجود تحسن في محتوى السكريا ات الكلية في نسيج الكبد.

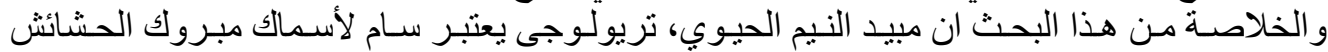

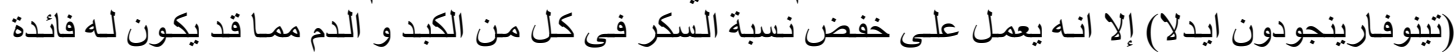

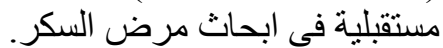

